\title{
DIMENSI SAINS DALAM KISAH AL-QUR'AN DAN RELEVANSINYA DENGAN KEAKURATAN PEMILIHAN KATA
}

\author{
Yusuf Baihaqi \\ Universitas Islam Negeri Raden Intan Lampung \\ baihaqi_yusuf@yahoo.com
}

\begin{abstract}
Although Al-Qur'an constitutes the book of guidance, it contains many verses related to modern sciences. Advanced scientific development in this modern century makes efforts to connect Al-Qur'an with sciences a must. The relationship between AlQur'an and sciences can be seen from some verses related to stories. This is examplified by, for example, the use of the word al-Malik not Fir'awn for the Egypt ruler in the reign of Prophet Josep. Al-Qur'an also uses the word female ant for the leader of ant group that encountered Solomon and its troop. Finally, Al-Qur'an also uses term "three darknesses" in the womb to refer to three stages an infant passed through before its born.
\end{abstract}

Keywords: Al-Qur'an, Story, Sciences

Abstrak. Al-Qur'an walaupun diturunkan sebagai kitab suci pemberi petunjuk, akan tetapi termuat dalam kandungannya banyak pembahasan seputar sains. Perkembangan sains di abad modern ini yang sangat pesat, dan keberadaan ayat Al-Qur'an yang sangat banyak yang dapat dikaitkan dengan sains, menjadikan upaya untuk mengaitkan AlQur'an dengan sains sebuah keniscayaan. Keterkaitan antara Al-Qur'an dengan sains pun terlihat pada pembahasan ayat-ayat kisah. Bahkan keberadaan sejumlah kata kunci dalam redaksi ayat kisah menguatkan keterkaitan antara Al-Qur'an dan sains, seperti: penyebutan kata "al-Malik" bukan "Fir'aun" untuk menunjukkan penguasa negeri Mesir di era nabi Yusuf as, penyebutan "Semut Betina" bagi pemimpin gerombolan semut yang berpapasan dengan nabi Sulaiman as dan bala tentaranya, dan bahwasannya ada "tiga kegelapan" yang dilalui dan yang meliputi janin prakelahirannya.

Kata Kunci: Al-Qur'an, Kisah, Sains 


\section{Pendahuluan}

Mengkaji ayat kisah tidak akan ada habisnya, bukan saja dikarenakan jumlahnya yang sangat banyak, sekitar sepertiga bahkan lebih dari jumlah ayat dalam Alquran, akan tetapi juga dikarenakan ayat kisah dapat dikaji dengan beragam lintas dimensi: dimensi ekonomi, dimensi sains, dimensi politik, dimensi peradaban, dimensi hukum dan dimensi-dimensi lainnya.

Dimensi sains merupakan salah satu dimensi yang bisa dikaji melalui ayat-ayat kisah. Mengkaji dimensi sains melalui ayat-ayat kisah dapat menghadirkan kenyataan bahwasannya Alquran merupakan sebuah kitab suci yang up to date sepanjang masa. Fenomena kesesuaian antara ayat-ayat kisah dengan perkembangan sains modern, disamping menghadirkan pencerahan bahwasannya antara Islam dan sains merupakan sebuah kesatuan yang tidak dapat dipisahkan, juga merupakan bagian dari pembuktian bahwasannya Alquran bukanlah karya manusia, sebagaimana yang kerap dituduhkan kepadanya bahwasannya ia merupakan karya Muhammad, sosok yang menyampaikannya kepada umat manusia, melainkan ia merupakan karya Dzat Yang Maha Segalanya, Pencipta alam semesta ini.

Lebih spesifik, guna lebih membuktikan betapa detail dan rincinya dimensi sains yang dapat dikaji dari ayat-ayat kisah, kita dapatkan dalam sejumlah redaksi ayat Alquran, pemilihan sejumlah kata yang sangat tepat dan akurat, yang tidak tergantikan dengan kata-kata yang lain, dimana kata-kata tersebut merupakan kata-kata kunci dari terkuaknya kesesuaian antara kandungan kisah Alquran pada satu sisi, dan sejumlah penemuan ilmiah pada sisi lainnya. Sebuah fenomena yang sudah diisyaratkan oleh Alquran dalam surah Hûd [11]: 1, bahwasannya ayat-ayat yang terkandung dalam Alquran tersusun secara rapi, dan Dzat Yang Menurunkan ayat-ayat tersebut merupakan Dzat Yang Memiliki tingkat ketelitian yang paripurna.

Mengomentari kandungan firman Allah swt dalam surah Hûd [11]: 1, seorang pakar tafsir Alquran berkebangsaan Indonesia yang bernama M. Quraish Shihab menulis dalam kitab

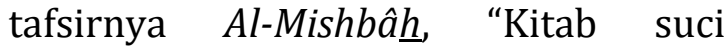
Alquran merupakan kitab suci yang telah mendapatkan penjagaan dari segala bentuk kekurangan, terjauhkan dari dari segala bentuk kekeliruan, ketidakbenaran dan kepalsuan, kitab suci Alquran merupakan kitab suci yang susunan kandungannya, seperti; susunan kata-katanya dan susunan ayat dan surahnya, tersusun sedemikian rapi, juga serasi, dalam artian: kata dan kalimatnya tidak tergantikan dengan kata dan kalimat yang lain, karenanya tidak ada celah untuk merubah atau mengeritiknya". ${ }^{1}$

Tulisan ini ditulis guna menghadirkan sejumlah fenomena diatas, dan sebagai sumbangsih dalam rangka mengkaji lebih mendalam seputar dimensi sains dalam kisah Alquran di kemudian hari. Tulisan ini ditulis berdasarkan kajian pustaka. Diawali dengan pembahasan seputar kisah Alquran, kemudian pembahasan seputar kaitan antara Alquran dan sains, berikutnya beberapa contoh kongkrit dari pemilihan kata dalam redaksi Alquran yang dapat dikaji dengan pendekatan sains, dan terakhir adalah penutup.
1 M. Quraish Shihab, Tafsîr Al-Mishbâh (Jakarta: Lentera Hati, 2002), h. 537. 


\section{Makna Kisah}

Kisah merupakan kata serapan dari bahasa Arab, yakni: al-Qishshah. Asal kata dari kata al-Qishshah adalah Qashsha Yaqushshu,dicontohkan: Qashsha asy-Syai'a hal ini bermakna: Tatabba'a Atsarahu (menyisir jejak). Dalam contoh yang lain, dikatakan Qashsha al-Qishshata hal ini bermakna: Rawâhâ (mengisahkannya). Kata alQishshah itu sendiri memiliki makna alKhabar (berita). ${ }^{2}$ Diantara makna lain yang dimiliki oleh kata adalah Dharaba (memukul), dalam sebuah contoh kalimat dicontohkan: Qashsha Fulânun Fulânan, contoh kalimat ini bermakna: bahwasaannya seseorang telah memukul seseorang yang lain. ${ }^{3}$

Adapun makna dari kata alQishshah secara istilah, seorang pakar bahasa Arab berkebangsaan Mesir yang bernama Ibrahim Anis dalam kamus alMu jam al-Wasith mendefiniskan kata al-Qishshah dengan Hikâyah Natsriyyah Thawîlah Tustamaddu Min al-Khayâl Aw al-Wâqi`Am Minhumâ Ma`an Wa Tubnâ 'Alâ Qawâ'id Mu 'ayyanah Min al-Fann alKitâbi (cerita panjang dalam bentuk prosa, yang berasal dari khayalan semata atau fakta sejarah atau berasal dari keduanya, dimana cerita ini dibuat berdasarkan ketentuan tertentu dari seni menulis). ${ }^{4}$

Definisi al-Qishshah diatas, untuk diterapkan pada kisah-kisah yang ditulis oleh manusia dalam hemat kami tidaklah bermasalah, akan tetapi untuk dinisbatkan kepada kisah Alquran, dalam hemat kami definisi diatas kuranglah tepat.

Kekurangtepatan definisi alQishshah diatas untuk dinisbatkan

2 Ibrahim Anis, al-Mu jam al-Wasîth, (Kairo: Majma` al-Lughah al-`Arabiyyah, t.th), h. 774. kepada kisah Alquran, dikarenakan kisah Alquran merupakan bagian dari firman Allah swt, dan semua firman Allah swt merupakan kebenaran, tidak terkandung sedikitpun di dalamnya kebohongan. Hal ini sebagaimana ditegaskan dalam banyak ayat Alquran, seperti firman-Nya dalam surah al-Kahfi [18]: 13.

Pada sisi lain, kisah Alquran tidak semuanya dikisahkan secara panjang lebar dan utuh apalagi berdasarkan kronologis kejadiannya, seperti: kisah nabi Yusuf as yang diabadikan dalam surat Yûsuf dalam 99 ayat.

Ada banyak kisah yang dikisahkan oleh Alquran, dimana kisah-kisah tersebut diabadikan oleh Alquran sebatas potongan-potongan kisah yang pentingnya saja, untuk dijadikan pelajaran bagi manusia yang membaca kisahnya, seperti: kisah Qarun yang diabadikan dalam surat al-Qashash dalam 8 ayat saja.

Atau bahkan Alquran dalam kisahnya, sebatas menyebut tokoh kisah dalam sebuah kalimat sisipan, diantara pemaparan kisah-kisah yang lain. Seperti: disisipkannya sekilas tentang sosok nabi Idris as, yang bisa kita pembahasan seputarnya dalam surah Maryam hanya dalam 2 ayat.

\begin{tabular}{llrr}
\multicolumn{1}{c}{ Alquran } & \multicolumn{2}{c}{ merupakan } & sumber \\
sejarah yang & orisinil dan otentik, & delah \\
dikarenakan & Allah swt & telah \\
menjadikannya & sebagai kitab & suci \\
pengawas atas kitab suci-kitab suci & suar \\
sebelumnya, sehingga sangat masuk \\
diakal kalau demikian status Alquran \\
dihadapan kitab suci-kitab suci \\
sebelumnya, apalagi Alquran untuk \\
dijadikan sebagai rujukan sejarah bagi
\end{tabular}

3 Abdul Latif Yusuf, Zubdah al-Mufradât, (Bairut: Dar al-Ma`rifah, 1998), h. 399.

4 Ibrahim Anis, al-Mu jam al-Wasîth, h. 774. 
kitab-kitab lainnya yang dihasilkan oleh olah pikir manusia yang terbatas. ${ }^{5}$

Alquran merupakan tolak ukur kebenaran, dikarenakan ia bersumber dari Dzat Yang Maha benar sebagaimana semua kandungannya adalah kebenaran, sehingga sangat masuk diakal karenanya Alquran memiliki tingkat ketepatan dalam pemilihan kata, kalimat dan maknanya. ${ }^{6}$ Tidak kita dapatkan dalam Alquran, satu kata pun yang diulang hanya untuk tujuan pengulangan minus makna, malainkan pengulangan itu terjadi untuk tujuan tertentu dan sangat akurat pada tempatnya, disamping makna yang tepat pula pada konteksnya. Tidak kita temukan dalam Alquran satu huruf, melainkan huruf-huruf tersebut mempunyai arti yang tepat, dan akan menjadi bias makna apabila huruf tersebut digantikan keberadaannya dengan huruf-huruf selainnya. ${ }^{7}$

Alquran diturunkan dengan tujuan agar ia menjadi kitab suci yang memberikan petunjuk bagi manusia, dalam semua lini kehidupan manusia, sebagaimana yang difirmankan dalam surah al-Baqarah [2]: 2.

Alquran walaupun terkandung di dalamnya berbagai macam pembahasan seputar sains, semisal: pembahasan seputar astronomi, sejarah, kedokteran, geologi, geografi, zoology, .....dll. tetap saja Alquran tidak bisa diposisikan sebagai sebuah buku Sains.

Terkandung dalam kandungan Alquran pembahasan seputar hakekat Sains, seperti: sejarah. Pemaparan sejarah dalam kandungan Alquran, sejatinya bertujuan untuk mengajak

${ }^{5}$ Lihat: Q.S. al-Mâ'idah [5]: 48.

${ }^{6}$ Lihat: Q.S. Hûd [11]: 1. siapapun yang membacanya untuk mempercayai Allah swt, dikarenakan pelajaran yang semestinya dapat dihasilkan dari bacaan terhadap kisah dalam Alquran adalah: hadirnya keyakinan seputar kemahatinggian, kemahakuasaan dan kemahatahuan Dzat yang mengisahkan kisah-kisah tersebut kepada manusia.

Disinilah, seorang mufassir dituntut untuk bisa lebih memahami dan menyadari karakter khusus yang menjadi ciri khas Alquran dan yang menjadi pembeda dengan sumbersumber sejarah lainnya. Seorang mufasssir ketika menafsirkan kisah Alqur'an, semestinya kisah tersebut tidaklah ditafsirkan panjang lebar menjauh dari tujuan Alquran diturunkan, dikarenakan penafsiran semacam ini akan memposisikan mufassir tersebut dalam posisi yang dilematis. Seperti: pada satu sisi, mungkin ia berhasil memuaskan manusia pada pemenuhan aspek Sains, akan tetapi pada sisi lain, ia tidak konsentrasi untuk menghadirkan Alquran sebagai kitab petunjuk bagi manusia, sebagaimana yang menjadi misi utama diturunkannya. ${ }^{8}$

\section{Antara Al-Qur'an dan Sains}

Alquran merupakan kitab suci yang sangat peduli dengan sains, Alquran mendorong manusia dalam hidup ini menjadi seorang saintis, membaca semacam firman Allah swt dalam surah al-Zumar [39]: 9, Alquran dalam redaksi tanya akan tetapi bermakna penegasan, menegaskan kepada kita sesungguhnya tidaklah

7 Abdus Satar Fathallah, al-Madkhal Ilâ atTafsîr al-Maudhû'i, (Kairo: Dar al-Tauzî Wa alNasy al-Islâmiyyah, 1991 M), Cet. II, h. 79-80.

${ }^{8}$ Abdus Satar Fathallah, al-Madkhal Ilâ alTafsîr al-Maudhû'i, h. 82-83. 
sama, dan tidak boleh diposisikan sama antara orang yang berilmu (seperti: saintis) dengan orang yang tidak berilmu.

Ayat tersebut sudah lebih dari cukup guna memberikan gambaran kepada kita, betapa Alquran merupakan sebuah kitab suci yang menyokong perkembangan sains dan mendorong manusia untuk terus meningkatkan kompetensi penguasaan sains dalam dirinya. ${ }^{9}$

Sains atau dalam bahasa Arab al'Ilm tersebut ratusan kali dalam redaksi Alquran, dengan berbagai macam ragam dan bentuknya. Sebagaimana ayat pertama yang diturunkan oleh malaikat Jibril kepada nabi Muhammad saw disaat beliau berada di gua Hira, adalah ayat yang memerintahkan beliau untuk membaca: Iqra' Bismi Rabbikalladzî Khalaqa ${ }^{10}$ (bacalah ya Muhammad atas nama tuhanmu yang menciptakan alam semesta ini). Dan membaca merupakan pintu masuk bagi seseorang untuk untuk menjadi seorang saintis. Disini terlihat jelas, urgensi dan korelasi antara Islam dan sains.

Pena dan apa yang ditulisnya (Nun Wa al-Qalami Wa Mâ Yasthurūn) 11 merupakan redaksi ayat pertama dari surat Nûn, dan surat Nûn merupakan bagian dari kelompok surah-surah pertama yang turun kepada nabi Muhammad saw. Bahkan Imam alSuyuthi dalam salah satu karya monumentalnya yang berjudul al-Itqân Fî̀ 'Ulûm al-Qur'ân menyebutkan bahwasannya surah Nûn merupakan surah kedua dari sisi urutan turunnya, setelah surat al-'Alaq. ${ }^{12}$ Penyebutan

9 Muhammad Ahmad al-Ghamrawi, alIslâm Fî 'Ashr al-'Ilmi, (Kairo: Dar al-Insan, 1991 M), Cet. IV, h. 42.

${ }^{10}$ Q.S. al-`Alaq [96]: 1.

${ }^{11}$ Q.S. al-`Alaq [96]: 1. pena di masa-masa awal turunnya Alquran, memberikan pesan khusus pentingnya proses pencatatan. Sebagaimana kaitan antara sains dan pencatatan sangatlah jelas, dimana keberlangsungan sains akan terus terjamin berbarengan dengan terjaminnya keberlangsungan proses pencatatannya, demikian pula sebaliknya.

Perintah membaca yang terkandung dalam surat al-'Alaq dan perintah menulis yang terkandung dalam surat Nûn, menunjukkan bahwa penguasaan ilmu/sains merupakan keistimewaan yang dimiliki oleh manusia atas makhluk-makhluk lainnya, bahkan dari jenis malaikat sekalipun. karenanya manusia diberikan amanah oleh Tuhan untuk menjadi khalifah di bumi ini, dimana status khalifah dituntut untuk dapat mengeksplorasi rahasia yang terkandung di alam semesta ini dan memanfaatkannya guna kesuksesan mengemban tugas tersebut. ${ }^{13}$ Sebuah pesan Alquran yang sangat kuat yang menegaskan bahwa ilmu/sains merupakan hal yang sangat urgent dan tidak dapat dipisahkan dari ajaran Islam.

Beberapa redaksi yang digunakan oleh Alquran untuk menguatkan keterkaitan antara Alquran dengan sains, dan bahwasannya sains merupakan hal yang sangat urgent dan tidak bisa dipisahkan dari ajaran Islam adalah: Ya 'lamûn, Âlimîn dan 'Ulamâ'.

Contoh $\begin{gathered}\text { penggunaan kata } \\ \text { (orang-orang yang }\end{gathered}$
ma lamûn yetahui): dalam surah al-An âm [6]:
97, Alquran mengingatkan
bahwasannya bintang-bintang di langit

12 Jalaluddin al-Suyuthi, al-Itqân Fî 'Ulûm al-Qur'ân, (Damaskus: Dar Ibnu Katsir, 2000 M), Cet. IV, h. 1/81.

13 M. Quraish Shihab, Menabur Pesan Ilahi (Al-Quran Dan Dinamika Kehidupan Masyarakat), (Jakarta: Lentera Hati, 2006 M), Cet. II, h. 151. 
diciptakan oleh Allah swt bukan sebatas untuk menjadi petunjuk dalam kegelapan daratan dan lautan, melainkan pada penciptaanya benarbenar terdapat tanda-tanda yang menunjukkan kebesaran dan kekuasaan-Nya bagi orang-orang yang mengetahui.

Contoh penggunaan kata Âlimîn (orang-orang yang mengetahui): disebutkan dalam surah al-Rûm [30]: 22, bahwasannya fenomena penciptaan langit dan bumi yang menakjubkan dan fenomena perbedaan bahasa dan warna diantara manusia walaupun mereka semua berasal muasal dari asal yang sama, merupakan bagian dari tandatanda yang menunjukkan kebesaran dan kekuasaan Allah swt bagi orang-orang yang mengetahui.

Contoh penggunaan kata 'Ulamâ'
(para Ulama/kalangan saintis):
difirmankan dalam surah Fâthir [35]: 27-28, setelah sejumlah bukti yang menunjukkan kebesaran dan kekuasaan Allah swt di alam semesta ini, seperti: curah hujan dari langit yang menumbuhkan beraneka ragam buahbuahan (ilmu pertanian), bebatuan dengan berbagai macam warnanya dalam kandungan gunung-gunung (ilmu geografi),14 juga keberagaman dalam ciptaan manusia (ilmu sosiologi) dan hewan (ilmu zoologi). Allah swt tegaskan setelahnya, bahwasannya keberagaman fenomena di alam semesta ini semestinya dapat menghadirkan rasa takut dalam diri manusia atas kebesaran dan kekuasaan Allah swt. Dan para Ulama merupakan kelompok manusia yang mampu untuk menghadirkan rasa takut itu dalam diri mereka.

14 Lihat: Tim Penyempurnaan Al-Qur'an dan Tafsirnya, Al-Qur'an dan Tafsirnya, (Jakarta: Departemen Agama RI, 2009), Cet. IV, h. 8/162.

15 Muhammad Ahmad al-Ghamrawi, alIslâm Fî̀ 'Ashr al-'Ilmi, h. 44.
Sangat jelas, merujuk kepada tiga ayat diatas, bahwasannya masuk dalam katagori 'Ulamâ' dalam perspektif Alquran adalah para saintis, yakni: mereka yang memahami rahasia penciptaan alam semesta ini yang banyak diisyaratkan oleh ayat-ayat kauniyyah. para 'Ulamâ' dengan spesifikasi seperti ini, ketika mereka beriman, maka keimanan mereka akan menghantarkan kepada rasa takut kepada Dzat pencipta alam semesta ini, dikarenakan pemahaman mereka seputar rahasia penciptaan alam semesta ini menjadikan mereka lebih merasakan kebesaran dan kekuasaan Allah swt yang terbentang luas. inilah sejatinya, hikmah dibalik perintah Allah swt terhadap manusia dalam sejumlah firman-firman-Nya dalam Alquran agar mereka mau memperhatikan dan memikirkan ciptaan-ciptaan-Nya yang terbentang luas di langit maupun yang di bumi. ${ }^{15}$

Kita sepakat bahwasannya Alquran bukanlah merupakan kitab sains, melainkan ia diturunkan untuk dijadikan sebagai kitab petunjuk bagi manusia. Akan tetapi, pembahasan Alquran dalam banyak ayatnya seputar alam semesta, dan objek kajian sains itu sendiri adalah alam semesta, serta terdapatnya kesesuaian antara kandungan Alquran dengan hakikat sains seputar pembahasan alam semesta, merupakan sebuah fenomena yang menunjukkan titik temu yang tidak dapat dipisahkan antara Alquran dan sains. ${ }^{16}$

Tidak dapat dipungkiri kemajuan sains yang begitu pesat pada abad modern ini, menuntut kita untuk

16 Muhammad al-Ghazali, Kaifa Nata ’âmal Ma 'a al-Qur'ân, (Manshurah: Dar al-Wafa, 1997), Cet. V, h. 210. 
mengkaji lebih mendalam seputar kandungan Sains dalam kisah Alquran. Dikarenakan karakter Alquran itu sendiri yang bersifat universal dan komprehensif.

Mengkaji kandungan sains dalam kisah Alquran akan membuka wawasan kita dan menambah keimanan kita akan kebenaran Alquran. Lebih lagi disaat kita dihadapkan dengan banyaknya kajian yang dihasilkan oleh para pengkaji Alquran yang meragukan keotentikan dan kevalidan kisah Alquran.

Tidak tabu dan tidak ada yang harus dikhawatirkan dari upaya kita untuk menguak lebih mendalam dimensi sains dalam kisah Alquran, dikarenakan sejatinya tidak ada pertentangan antara Alquran dan hakikat sains, demikian sebagaimana yang disampaikan oleh Muhammad al-Ghazali dalam salah satu karya yang berjudul Kaifa Nata`âmal Ma`a al-Qur'ân.

Bahkan jauh sebelum Muhammad al-Ghazali, seorang ulama yang bernama Ibnu Taimiyyah pun dalam pernyataannya yang dikutip oleh banyak dari kalangan para Ulama setelahnya, menegaskan kepada kita betapa tidak mungkin terjadi pertentangan antara Alquran dan sains yang sudah bersifat paten dan berdasarkan eksperimen yang telah teruji kebenarannya. Kata beliau, La Yumkin An Yakun Hunâka Tanâqudhun Baina Shahîh al-Manqūl Wa Sharîh al-Ma`qūl (pertentangan tidak akan terjadi antara riwayat yang benar dan logika yang jelas).

Tidak demikian dengan sains yang masih sebatas teori dan belum ada kepastian dari sisi kebenarannya, kemungkinan benar dan salah masih sangat mungkin sekali, masih banyak

17 Ahmad Umar, al-Tafsîr al-'Ilmi Li alQur'ân Fî al-Mîzân, (Bairut: Dar Qutaibah, 1991), h. 83. kita temukan teori yang semacam ini bertolak belakang dengan Alquran. ${ }^{17}$

Oleh karenanya, mengorelasikan kandungan teks Alquran dengan sains, semestinya dijauhkan apabila sains tersebut masih sebatas teori yang masih belum terbukti secara pasti kepastian dan kebenarannya. ${ }^{18}$

Tidak mungkin terjadi pertentangan antara kandungan kisah Alquran dan temuan sains, baik Alquran maupun sains sejatinya berasal dari Dzat yang sama, Pencipta alam semesta ini. Kisah Alquran adalah Âyât Qur'âniyyah, yakni; kumpulan firman Allah swt dalam bentuk bacaan.

Adapun sains adalah Âyât Kauniyyah, yakni; kumpulan fenomena alam yang tercipta di jagad raya ini. Dan keduanya, yakni; Âyât Qur'âniyyah dan Âyât Kauniyyah merupakan tanda-tanda yang sama-sama menunjukkan akan kebesaran dan kekuasaan Allah swt.

Adapun disaat kita dihadapkan dengan fenomena yang tidak bisa diharmonisasikan antara Âyât Qur'âniyyah dan Âyât Kauniyyah, seorang pakar tafsir Alquran dari Universitas al-Azhar, Mesir, yang bernama Ibrahim Khalifah menjelaskan:

Perbedaan semacam ini bisa dikarenakan sebatas perbedaan yang bersifat Zhâhir (yang tampak diluar), padahal hakekatnya tidak ada perbedaan diantara keduanya, sehingga tidak ada urgensinya untuk mengenyampingkan salah satu dari keduanya. Atau bisa juga perbedaan ini bersifat Haqîqî (sebenarnya), perbedaan yang bersifat Haqîqî semacam ini tidak mungkin diupayakan harmonisasi diantara keduanya.

18 Shalah Al Khalidi, I’jâz al-Qur'ân alBayânî Wa Dalâ'il Mashdarihi al-Rabbânî, (Amman: Dar `Ammar, 2000 M), h. 390. 
Disaat perbedaan yang terjadi antara Âyât Qur'âniyyah dan Âyât Kauniyyah bersifat Haqîqî, kebenaran yang dimiliki oleh Âyât Kauniyyah bisa berupa kebenaran yang bersifat Qath $i$ (pasti), bisa juga masih sebatas Zhanni (praduga).

Apabila Âyât Kauniyyah bersifat Zhanni, maka ia harus tunduk kepada Âyât Qur'âniyyah. Akan tetapi apabila Âyât Kauniyyah bersifat Qath `i, maka ada empat kemungkinan yang akan terjadi.

Kemungkinan Pertama, keduaduanya benar, ini merupakan sebuah kemustahilan, karena kebenaran tidaklah mungkin dihasilkan dari dua sumber yang saling bertentangan.

Kemungkinan Kedua, kebalikan dari yang pertama, kedua-duanya salah, inipun merupakan sebuah kemustahilan.

Kemungkianan membenarkan fenomena Âyât Qur'âniyyah dan mengenyampingkan fenomena Âyât Kauniyyah, hal ini juga tidak benar, tidak mungkin kebenaran fenomena Âyât Qur'âniyyah diperoleh dengan mengenyampingkan kebenaran fenomena Âyât Kauniyyah, dikarenakan disaat kita mengenyampingkan fenomena Âyât Kauniyyah, sejatinya disaat yang bersamaan kita juga mengenyampingkan Âyât Qur'âniyyah.

Apabila tiga kemungkinan diatas, tidaklah mungkin terjadi, maka yang tersisa adalah kemungkinan yang keempat. Yakni: dengan mengatakan bahwasannya yang dimaksud dari Âyât Qur'âniyyah bukanlah makna Zhahir nya. Kemudian apabila kita membolehkan pentakwilan ayat tersebut, maka kitapun berupaya untuk mentakwilkan ayat tersebut sehingga selaras dengan kandungan makna Âyât Kauniyyah yang

19 Lihat: Ibrahim Abdurrahman Muhammad Khalifah, al-Dakhîl Fî al-Tafsîr, bersifat Qath $i$, adapun apabila kita tidak membolehkan pentakwilan ayat tersebut, maka kita serahkan hakekat makna dari Âyât Qur'âniyyah kepada Allah swt, Dzat Yang Menurunkannya. ${ }^{19}$

\section{Dimensi Sains Dan Relevansinya Dengan Pemilihan Kata}

\section{Pemilihan Kata "al-Malik" Bagi Penguasa Negeri Mesir Dalam Kisah Nabi Yusuf as.}

Dalam pandangan para sejarawan, Alquran adalah rujukan sejarah yang paling asli dan benar apabila dibandingkan dengan rujukan-rujukan sejarah lainnya. Realita ini sangatlah beralasan apabila ditilik dari sisi kwalitas bagaimana teks Alquran tersebut diriwayatkan di samping kedudukannya sebagai kitabullah. Atas dasar itulah, sangatlah sulit bagi siapa saja di tilik dari dua aspek diatas, untuk meragukan keabsahan dan keotentikan kisah-kisah yang dipaparkan oleh Alquran.

Akan tetapi sangat disayangkan sekali ternyata kajian-kajian yang dilakukan oleh para sejarawan seputar sejarah klasik tidak banyak menyentuh dan mengutip apa yang diberitakan oleh Alquran, hal ini dikarenakan dominasi para pengkaji sejarah ketimuran dari kalangan barat yang lebih dikenal dengan orientalis dalam sumber kajian mereka, atau keriskanan sebagian sejarawan muslim untuk melakukan kajian lebih spesifik seputar sejarah yang dipaparkan oleh Alquran.

Kejadian diatas, suka atau tidak suka merupakan sebuah kerugian yang luar biasa yang dirasakan oleh para sejarawan yang berkonsentrasi dalam mengkaji sejarah klasik, dikarenakan mereka telah melalaikan sebuah

(Kairo: Diktat Perkuliahan Universitas al-Azhar, t.th), h. 266-276. 
referensi sejarah yang paling asli dan valid. Lebih daripada itu, yang lebih mencengangkan bahwasannya para sejarawan kekinian, baik yang berdomisili di wilayah barat maupun wilayah timur (muslim atau non muslim), mereka cenderung lebih melihat kepada Taurat dan Injil dibandingkan Alquran dalam mengambil rujukan kajian dan riset mereka. Seakan-akan Taurat dan Injil merupakan sumber utama dalam kajian sejarah klasik, padahal sebagian besar mereka mengetahui dan mengakui lemahnya kwalitas Taurat dan Injil dari sisi periwayatan keduanya, di samping keberadaan sejumlah hasil riset dan kajian yang sangat banyak sekali yang dilakukan oleh mereka-mereka yang mempercayai Taurat dan Injil sebagai kitab suci (lebih-lebih mereka-mereka yang tidak mempercayai keduanya) yang menyangsikan akan keorsinilan teks-teks keduanya, bahkan bentuk penyangsian tersebut sampai kepada ketika sebuah teks dinisbatkan kepada sosok yang tercantum di dalam keduanya. ${ }^{20}$

Tidak ada keraguan sedikitpun, bahwasannya Alquran telah memberikan sumbangsih yang tidak sedikit melalui penyampaian ayat-ayat kisah, akan berita-berita yang sangat penting dan asli seputar kejadiankejadian masa lalu baik di tilik dari dimensi politik, sosial, maupun ekonomi, di mana pemberitaan semacam ini adalah bagian dari bukti kongkrit yang menunjukkan kebenaran dakwah kenabian nabi Muhammad saw.

Bahkan kalau kita adakan sebuah studi komparatif antara Alquran dan al-

20 Bayoumi Mahran, Dirâsât Târîkhiyyah Min al-Qur'ân al-Karîm Fî Bilâd al-'Arab, (Iskandaria: Dar al-Ma`rifah al-Jami iyyah, 1995), h. 6-7.

${ }^{21}$ Lihat: Takwin $12: 14-20,39: 1,40: 2$ $21,41: 1-14,42: 15,47: 1-26$ dan $50: 4-7$ (al-
Kitab al-Muqaddas (taurat dan injil), ternyata banyak sekali dari kisah Alquran yang dibuktikan oleh hakekat penemuan ilmiah kontemporer yang meluruskan kesalahan-kesalahan pemberitaan yang termuat dalam Taurat dan Injil, ini semua dalam hemat kami termasuk bagian dari pembuktian akan kebenaran apa yang Allah swt firmankan dalam surah Yûsuf [12] : 111 seputar superioritas yang dimiliki oleh kitab suci Alquran atas kitab suci-kitab suci sebelumnya, dan bahwasannya kisah Alquran bukanlah merupakan kumpulan kisah yang diada-adakan.

Sebagai sebuah contoh kongkritnya, Taurat dalam pemaparan kisahnya, ketika berbicara tentang penguasa Mesir pada zaman nabi Yusuf dan Ibrahim Alaihimassalâm, selalu saja menggunakan redaksi "Fir'aun Misra".21 Tidak demikian dengan Alquran, dimana ia selalu menggunakan redaksi "al-Malik". ${ }^{22}$

Menyikapi perbedaan penggunaan redaksi dalam kedua kitab diatas, berkata para pemerhati Taurat: Bahwasannya hal ini (pemakaian redaksi yang termaktub dalam kitab Taurat) sesuai dengan kebiasaan yang berlaku pada abad kesembilan belas (19) dan kedelapan belas (18) sebelum masehi.

Realitanya ternyata berbicara lain, sejarah mencatat bahwasannya kata "Fir'aun" yang dalam bentuk Mesirnya "Bir'a" atau "Bir'u" memiliki arti pada awalnya: Sebuah rumah besar, dimana mereka menggunakannya untuk mengisyaratkan istana yang didiami oleh sang raja, bukan kepada sosok sang

Kitâb al-Muqaddas, (Kairo: Dar al-Kitab alMuqaddas, 2001), Cet. IV.

22 Disebut kata "al-Malik" seputar kisah nabi Yusuf as dalam lima (5) tempat: Q.S. Yûsuf [12]: 43, 50, 54, 72 dan 76. 
raja. Kemudian dengan perjalanan waktu, tepatnya semenjak keluarga kedelapan belas (18), kata tersebut berubah maknanya, dan yang dimaksud dengannya adalah sang raja itu sendiri.

Adapun kapan dimulai perubahan dalam pemakaian gelar "Fir'aun" bagi penguasa Mesir? A.H. Gardiner menyebutkan bahwa perubahan tersebut dimulai semenjak masa Tahutamas ${ }^{23}$ ketiga, di mana pada masa itu di mulai pemakaian gelar "Fir 'aun" bagi penguasa Mesir, dan diikuti oleh Akhnatun ${ }^{24}$ berdasarkan sebuah teks pidato pada masanya, kemudian gelar tersebut dipakai semenjak keturunan kesembilan belas (1308-1184 S.M.) dan terus berlanjut setelahnya.

Atas dasar itulah, dalam hemat kami Alquran dengan redaksi yang di milikinya hendak membedakan antara penguasa Mesir yang berkebangsaan asing pada masa nabi Yusuf as, dengan menamakannya sebagai "al-Malik". Dengan penguasa Mesir yang berasal dari pribumi Mesir pada zaman nabi Musa as, dengan menamakannya sebagai "Fir'aun". 25 Suatu kejelian redaksi yang dimiliki oleh Alquran, yang dapat membuktikan akan kebenarannya, dikarenakan ia sejalan dan sesuai dengan apa yang diinformasikan oleh penemuan ilmiah kontemporer.

Atas dasar itulah, bahwasannya penisbatan gelar "Fir'aun" bagi penguasa Mesir sebelum masa Tahutamas ketiga, merupakan sebuah

${ }^{23}$ Gelar yang diperuntukkan bagi keempat Fir`aun dari keturunan kedelapan belas (18). Lihat Louis Ma`luf, al-Munjid Fi al-A lâm, (Bairut: Dar al-Masyriq, t.th), Cet. XV, h. 169.

24 Raja Mesir dari keturunan kedelapan belas (18), dalam kepemimpinannya beliau melakukan perombakan besar-besaran dalam hal kepercayaan, istrinya bernama Nefertiti. Lihat Louis Ma`luf, al-Munjid Fi al-A 'lâm, h. 71. kesalahan dalam rentetan kejadian sejarah Mesir kuno. Dan kalau kita merujuk kepada Taurat, kita temukan bahwasannya semacam realitas sejarah di atas, tidaklah sejalan dengan kandungannya, dikarenakan ia menggunakan gelar "Fir'aun" pada sebuah masa dimana gelar "al-Malik" lah semestinya yang digunakan, sebaliknya ia menggunakan gelar "alMalik" pada masa dimana semestinya digunakan gelar "Fir'aun", yakni: semenjak keturunan kedelapan belas (18) dan setelahnya. ${ }^{26}$

Sesungguhnya kesesuaian sejarah yang dipaparkan oleh Alquran dengan penemuan ilmiah kontemporer, semacam penemuan para arkeolog diatas, merupakan sebuah bukti akan kebenaran Alquran. Sebaliknya ketidaksesuaian antara realitas sejarah dengan apa yang terkandung dalam Taurat dari paparan sejarahnya, lebih meyakinkan kita bahwasannya telah banyak terjadi distorsi dalam kitab Taurat yang ada pada kita sekarang, sebuah perubahan dan pemutarbalikan fakta dari aslinya hingga selaras dengan apa yang diinginkan oleh hawa nafsu para pemuka agama, kemudian mereka mengklaim setelahnya bahwa Taurat yang ada sekarang merupakan Taurat yang diturunkan kepada nabi Musa as. Sebuah kebohongan besar dimana Alquran pun mengabadikan kebohongan yang kerap mereka lakukan dalam surah al-Kahfi [18]: 5.

25 Lihat: Q.S. al-Baqarah [2]: 49, Q.S. alA'râf [7]: 103 dan Q.S. Thâha [20]: 24.

26 Bayoumi Mahran, Banû Isrâ'îl, (Iskandaria: Dar al-Ma`rifah al-Jami`iyyah, 1999 M), h. 3/229-231. Bayoumi Mahran, Dirâsât Târîkhiyyah Min al-Qur'ân al-Karîm Fi Misr, (Iskandaria: Dar al-Ma`rifah al-Jami iyyah, 1995), h. 121-122. 


\section{Pemilihan Kata "Qâlat" Yang Menunjukkan Semut Berjenis Betina Dalam Kisah Nabi Sulaiman as. ${ }^{27}$}

Ketika Alquran mengisahkan kisah seorang nabi, tidaklah semua yang berkaitan dengan nabi tersebut selama hidupnya diabadikan oleh Alquran. Hanya sebagian dari kisah nabi tersebut yang terpenting dan sarat dengan muatan pelajaran yang diabadikan oleh Alquran.

Diantara bagian penting dari kisah nabi Sulaiman as selama hidupnya yang diabadikan oleh Alquran, adalah kisah pertemuannya dengan sekawanan binatang semut yang diantaranya diabadikan oleh Alquran dalam surah al-Naml [27]: 18. Dimana dalam ayat tersebut, seeokor semut betina memberikan instruksi dan komando kepada sekawanan semut yang bersamanya agar memasuki sarang, untuk menghindari injakan kaki nabi Sulaiman as dan bala tentaranya.

Pengabadian kisah diatas, bukan saja dalam konteks pembahasan salah satu mu jizat yang dianugerahkan oleh Allah swt kepada nabi Sulaiman as, berupa kemampuan untuk memahami bahasa binatang, sebagaimana yang bisa kita baca dari redaksi ayat berikutnya, yakni: firman-Nya dalam surah al-Naml [27]: 19 Fatabassama

27 Diriwayatkan dari Qatadah: sewaktu hari dia memasuki kota Kufah, manusia pun berkumpul mengerumuninya, dia berkata: bertanyalah sekehendak kalian, dan Abu Hanifah saat itu yang masih berumur belia berada di tengah-tengah mereka. Kembali Qatadah berkata: bertanyalah kepadanya (Abu Hanifah), apakah semut nabi Sulaiman as jantan atau betina? Maka mereka pun bertanya kepadanya seputar itu, dia pun mampu memuaskan mereka dengan jawabannya. Abu Hanifah berkata: ia betina, dikatakan kepadanya: darimana kamu mengetahui bahwasannya ia betina? Dia berkata: dari kitabullah, yakni firmannya "Qâlat Namlatun", dikarenakan kalau ia jantan, tentunya

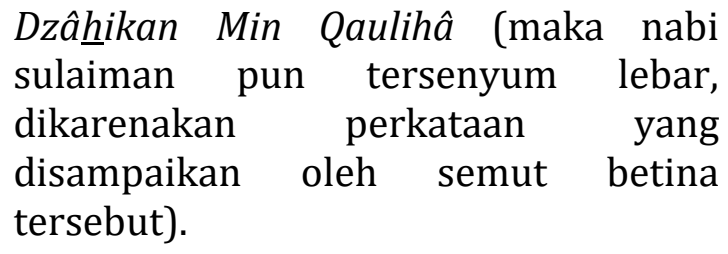

Melainkan juga, ayat diatas sarat dengan dimensi sains, apalagi ketika kita berupaya mengetahui kenapa pada redaksi ayat di atas, Alquran lebih memilih kalimat "Qâlat Namlatun", yang menunjukkan bahwasannya yang berkata pada kisah tersebut adalah seekor semut betina, bukan semut jantan.

Diantara dimensi sains yang bisa kita pelajari dari ayat diatas, bahwasannya kawanan semut hidup secara berkelompok dengan struktur sosial dan pembagian kerja yang sangat efisien. $^{28}$ Pernyataan seekor semut betina yang diabadikan pada ayat diatas, sangat jelas menunjukkan sesuatu yang menonjol dalam kerajaan semut berkaitan dengan keberadaan sebuah sistem yang rapi, dimana semua bagian dari kerajaan tersebut mengetahui apa yang menjadi tanggung-jawabnya masing-masing. Sebagai contoh: tugas ratu semut dalam kisah diatas yang bertugas sebagai semut penjaga, dimana ia bertugas untuk mengawasi cuaca dan kondisi di sekitarnya, seakan-akan ia berposisi sebagai tentara pemantau yang

bunyi firman-Nya adalah "Qâla Namlatun", dikarenakan kata "Namlatun", sama seperti kata "al-Hamâmatu (Burung Dara)" dan "al-Syâtu (Kambing)" yang dapat diperuntukkan untuk jantan atau betina, yang membedakan diantara keduanya hanyalah tanda yang menunjukkannya, seperti: Huwa (kata ganti yang menunjukkan jantan) atau Hiya (kata ganti yang menunjukkan betina). Lihat Fakhruddin al-Razi, al-Tafsîr alKabîr, (Kairo: Dar al-Hadis, 2012), h. 427.

28 Tim Penyusun Tafsir Ilmi, Hewan Dalam Perspektif Alquran dan Sains, (Jakarta: Lajnah Pentashihan Mushaf Alquran, 2012), h. 255. 
diharuskan memiliki kejelian dan kepekaan tingkat tinggi. ${ }^{29}$

Dimensi sains yang juga dapat kita simpulkan dari ayat diatas melalui kajian ilmu serangga, bahwasannya semut memiliki bahasa yang digunakan untuk saling berkomunikasi sesamanya, fenomena ini pun telah dibuktikan oleh banyak penelitian kontemporer dengan menggunakan sejumlah perangkat ilmiah yang canggih, yang menyatakan bahwasannya kehidupan sosial semut terjadi berdasarkan kesepahaman diantara sesama. ${ }^{30}$

Alquran ketika mengabadikan sebuah kisah, Alquran mengabadikannya sesuai dengan fakta, bukan saja fakta yang tampak, terlihat dan terdengar, bahkan Alquran pun mampu mengabadikan bagian-bagian dari sebuah kisah yang tidak tampak, tidak terlihat dan tidak terdengar sekalipun, kemampuan ini sangatlah dimungkinkan dimiliki oleh kisah Alquran, dikarenakan Alquran berasal dari Allah swt, Dzat Yang Mengetahui semua yang nyata bahkan yang ghaib sekalipun.

Kata per kata yang dikatakan oleh ratu semut sebagaimana yang diabadikan oleh Alquran, sejatinya secara faktual, kata-kata itulah memang yang dikatakan oleh ratu semut tersebut.

Sebagian Ulama ketika mencermati kata-kata yang dikatakan oleh ratu semut pada ayat diatas, menyimpulkan bahwasannya kata-kata tersebut menunjukkan bahwasannya ratu semut tersebut memiliki tingkat intelegensia yang tinggi. Dikarenakan

29 Muhammad Mutawalli al-Sya`rawi, Tafsîr al-Sya'râwî, (Kairo: Akhbar al-Yaum, 1991), h. 17/10759.

30 Muhammad Kamil Abdush Shamad, alI’jâz al-'Ilmi Fî al-Islâm (al-Qur'ân al-Karîm), tidaklah mungkin kata-kata tersebut terlontar melainkan dari makhluk yang dianugerahi oleh Dzat Yang Menciptakannya kemampuan intelegensia yang tinggi.

Bunyi potongan redaksi surah alNaml [27]: 18: Kata "Yâ" menunjukkan bahwasannya semut tersebut memanggil. Kata "Ayyuhâ" menunjukkan bahwasannya semut tersebut menggingatkan. Kata "alNamlu" menunjukkan bahwasannya semut tersebut melihat. Kata "Udkhulû" menunjukkan bahwasannya semut tersebut memerintah. Kata "Masâkinakum" menunjukkan bahwasannya semut tersebut menasehati. Kalimat "Lâ Yahthimannakum" menunjukkan bahwasannya semut tersebut memperingatkan. Kata "Sulaimân" menunjukkan bahwasannya semut tersebut menyebut secara khusus. kalimat "Wajunûduhû" menunjukkan bahwasannya semut tersebut menyebut secara umum. Kalimat "Wahum Yâ Yasy 'urûn" menunjukkan bahwasannya semut tersebut memaklumi. ${ }^{31}$

Demikian, Sebuah kesimpulan berdasarkan kata-kata, yang ternyata sangat sesuai dengan penemuan para ilmuan di bidang ilmu serangga, dimana setelah melalui uji coba ilmiah yang mereka lakukan, mereka pun menyimpulkan bahwasannya diantara kelebihan yang dimiiki oleh semut dibandingkan dengan hewan lainnya, adalah kepintaran yang luar biasa yang dimilikinya.

Sebagai contoh; kawanan semut terlebih dahulu akan memecahkan biji yang mereka dapatkan sebelum

(Kairo: al-Dar al-Mishriyyah al-Libnaniyyah, 1996), Cet. IV, h. 165.

31 Muhammad Ali al-Shobuni, Shafwat alTafâsîr, (Kairo: Dar al-Shobuni, t.th.), Cet. IX, h. 2/405-406. 
menyimpannya di tempat penyimpanan, agar biji tersebut tidak dapat tumbuh. Sebagaimana biji-bijian yang tidak dapat dipecahkan, selalu dengan sengaja dan berulang-ulang dipanaskan dibawah terik matahari oleh kawanan semut, agar tidak basah dan lembab kemudian tumbuh menjadi tumbuhan. ${ }^{32}$

Disamping dimensi sains sebagaimana yang terkandung dalam kisah ratu semut diatas, penelitian dalam dunia serangga pun menghasilkan kesimpulan, bahwasannya dalam setiap kerajaan semut, ada seekor ratu semut (bukan raja) yang menjadi pemimpin dalam kerajaan tersebut, dimana semua anggota dalam kerajaan tersebut tunduk dengan apa yang menjadi keputusan sang ratu. Dalam dunia serangga, adalah hal biasa sosok betina yang menjadi pemimpin, dikarenakan bentuk tubuhnya yang besar, disamping itu juga bahwasannya serangga jantan peranan yang dimilikinya tidak sepenting peranan yang dimiliki oleh serangga betina. ${ }^{33}$ hakekat ilmiah semacam ini, tentunya juga sangat selaras, dengan pemilihan kata yang dipilih dalam redaksi Alquran, dimana Alquran menggambarkan pemimpin kerajaan semut yang berpapasan dengan nabi Sulaiman as dan bala tentaranya, dengan seekor semut berjenis betina bukan berjenis jantan.

\section{Pemilihan kata "Zhulumât" Dalam Mengisahkan Kehidupan Janin.}

32 Muhammad Kamil Abdush Shamad, alIjâzz al-'Ilmi Fî al-Islâm (al-Qur'ân al-Karîm), h. 167.

${ }^{33}$ Abdul Basith Jamal \& Dalia Shadiq Jamal, Alquran dan Sains: Kehidupan Sosial Semut, www.republika.co.id, diambil pada tanggal 14 September 2017.
Disaat Alquran diturunkan, peradaban manusia belumlah mengenal sejumlah perangkat medis yang canggih semacam USG (ultrasonografi) yang dapat mendeteksi kehidupan janin. Nabi Muhammad saw yang menyampaikan Alquran pun bukanlah seorang pakar medis yang memiliki pengetahuan seputar keadaan dan tahapan-tahapan kehidupan yang dilalui oleh janin.

Keberadaan ayat dalam Alquran berkaitan dengan kehidupan janin, yang di kemudian hari dibuktikan kebenarannya secara ilmiah, merupakan bagian dari fenomena yang membenarkan bahwasannya Alquran bersumber dari Allah swt.

Di sebutkan dalam surah azZumar [39]: 6, ada tiga kegelapan atau dalam redaksi Alquran disebut sebagai Zhulumât Tsalâts, yang menyelimuti janin pra kelahirannya.

Ibnu Asyur, seorang pakar tafsir berkebangsaan Tunisia menjelaskan bahwasannya "Zhulumât Tsalâts (tiga kegelapan)" yang dimaksud pada ayat tersebut adalah: kegelapan perut, kegelapan rahim, dan kegelapan ariari. $^{34}$ Senada dengannya, Sayyid Thanthawi, seorang pakar tafsir berkebangsaan Mesir juga dalam kitab tafsirnya menerangkan bahwasannya yang dimaksud dengan tiga kegelapan pada ayat diatas adalah tiga kegelapan yang sama, sebagaimana yang dijelaskan oleh Ibnu Asyur. ${ }^{35}$

Penafsiran diatas, sangat selaras dengan hasil kajian yang dihasilkan oleh para ahli peneliti yang menemukan

34 Muhammad al-Thahir Ibnu Asyur, Tafsîr al-Tahrîr Wa al-Tanwîr, (Tunisia: Dar Suhnun, 1997), h. 23/334.

35 Muhammad Sayyid Thanthawi, al-Tafsîr al-Wasîth Li al-Qur'ân al-Karîm, (Kairo: Dar alSa`adah, 2007), h. 12/198. 
adanya tiga lapis membran -ayat di atas menyebutnya sebagai "tiga kegelapan"yang dapat menjamin keamanan janin selama berada di dalam rahim. beberapa ahli peneliti kemudian menafsirkan "tiga kegelapan" itu dengan tiga lapisan membran amniotik yang mengelilingi rahim, dinding rahim, dan dinding abdomen di bagian perut, yaitu:

- Lapisan membran amnion.

- Lapisan membran chorion.

- Lapisan membran decidua. ${ }^{36}$

Disamping penafsiran diatas seputar apa yang dimaksud dengan "Zhulumât Tsalâts", Tim Tafsir Alquran yang dibentuk oleh Kementerian Urusan Waqaf Republik Arab Mesir, lebih memilih pendapat yang mengatakan bahwasannya "Zhulumât Tsalâts" yang dimaksud pada ayat diatas adalah: biji kemaluan laki-laki, indung telur perempuan dan rahim, dikarenakan ketiga kegelapan tersebut merupakan tiga kegelapan yang berbeda di tempat yang terpisah. ${ }^{37}$ Pendapat yang sama juga ditulis Muhammad Washfi dalam bukunya alQur'ân Wa al-Thibb, menurut beliau: air mani berada di biji kemaluan laki-laki, sehingga biji kemaluan laki-laki tersebut dianggap sebuah kegelapan. Dan ovum berada di indung teler perempuan, sehingga indung telur perempuan tersebut dianggap sebagai sebuah kegelapan. Dan apabila kemudian air mani laki-laki dan ovum perempuan bertemu sehingga menjadi janin dalam rahim, maka rahim tempat

36 Tim Penyusun Tafsir Ilmi, Penciptaan Manusia Dalam Perspektif Alquran dan Sains, (Jakarta: Lajnah Pentashihan Mushaf Alquran, 2012), h. 84.

37 Tim Penyusun Tafsir Alquran, alMuntakhab Fî Tafsîr al-Qur'ân al-Karîm, (Kairo: Kementerian Wakaq Republik Arab Mesir, 2000), Cet. XIX, h. 684. berkembang biaknya janin merupakan sebuah kegelapan, dan merupakan kegelapan yang ketiga. ${ }^{38}$

Perbedaan penafsiran diatas sejatinya tidaklah mencederai Alquran, dan Alquran tidaklah bisa dipersalahkan dikarenakan perbedaan penafsiran diantara para ahli tafsir. Tafsir Alquran merupakan produk yang dihasilkan dari ijtihad manusia, sesuai dengan kemampuan manusia tersebut, yang bisa jadi salah, bisa jadi benar.

Yang terpenting bahwasannya dua penafsiran diatas tidaklah bertolak belakang dengan redaksi Alquran, bahkan kita dapatkan dimungkinkannya redaksi Alquran untuk ditafsirkan dengan kedua penafsiran tersebut. Fenomena semacam ini menguatkan adanya keberagaman makna yang dimiliki oleh redaksi Alquran. Rasulullah saw jauh hari telah mengisyaratkan akan hal ini dalam sabdanya, "al-Qur'ân Dzalūlun Dzū Wujūhin Fahmilūhu 'Alâ Ahsani Wujūhihi (Alquran itu mudah dan memiliki beberapa makna, maka ambillah yang terbaik dari maknamakna yang dimilikinya)".39

\section{Penutup}

Tidak semua definisi kisah bisa diterapkan atas kisah Alquran, ada sujumlah hal yang mendasar yang membedakan kisah alquran dengan kisah-kisah selainnya, diantaranya: kisah Alquran merupakan kisah yang asli dan benar. Semua redaksi yang dipakai dalam kisah Alqur'an

38 Muhammad Washfi, al-Qur'ân Wa alThibb, (Bairut: Dar Ibnu Hazm, 1995), h. 55.

39 al-Daruquthni, Sunan al-Dâruquthnî, bab. An Nawadir, h. 10/56, nomor hadits. 4321 (Program Maktabah al-Syamilah, Edisi Kedua). 
merupakan redaksi yang tepat dan Alquran hendaknya selalu diposisikan sebagai kitab petunjuk.

Korelasi kuat terdapat antara Alquran dan sains, korelasi antara keduanya terlihat dengan dorongan Alquran pada sejumlah ayatnya kepada manusia untuk menjadi seorang saintis, keberadaan sejumlah redaksi Alquran yang menguatkan pentingnya penguasaan sains, terkuaknya sejumlah kesesuaian antara teks Alquran dan sejumlah teori ilmiah, bahkan tidak terdapatnya kontradiksi antara teks Alquran dengan hakekat ilmiah yang ditemukan oleh sejumlah kalangan saintis, semua ini menguatkan korelasi antara Alquran dengan sains.

Alquran merupakan kitab suci dimana kata-katanya tersusun secara rapi dan akurat. Kerapian dan keakuratan kata-kata Alquran inilah diantaranya yang menghasilkan sisi kesesuaian antara antara Alqur'an dengan sains. Dalam konteks sejumlah ayat kisah, bisa kita baca pada pemilihan kata "al-Malik" Bagi penguasa negeri Mesir dalam kisah nabi Yusuf as, pemilihan kata "Qâlat" yang menunjukkan semut berjenis betina dalam kisah nabi sulaiman as, dan pemilihan kata "Zhulumât" dalam mengisahkan kehidupan janin.

\section{DAFTAR PUSTAKA}

al-Daruquthni, Sunan al-Dâruquthnî, Program Maktabah al-Syamilah, Edisi Kedua

al-Ghamrawi, Muhammad Ahmad., alIslâm Fî̀ 'Ashr al-'Ilmi, Cet. Ke-4, Cairo: Dar al-Insan, 1991

al-Ghazali, Muhammad., Kaifa Nata 'amal Ma'a al-Qur'ân, Cet. Ke-5, Manshurah: Dar al-Wafa, 1997
al-Khalidi, Shalah., I’jâz al-Qur'ân alBayânî Wa Dalâ'il Mashdarihi alRabbânî, Amman: Dar 'Ammar, 2000

al-Kitab al-Muqaddas, Cet. Ke-4, Cairo: Dar al-Kitab al-Muqaddas, $2001 \mathrm{M}$

Al-Qur'an

al-Razi, Fakhruddin., al-Tafsîr al-Kabîr, Cairo: Dar al-Hadis, $2012 \mathrm{M}$

al-Sya`rawi, Muhammad Mutawalli., Tafsîr al-Sya 'râwî, Cairo: Akhbar alYaum, 1991

al-Shobuni, Muhammad Ali., Shafwat alTafâsîr, Cet. Ke-9, Kairo: Dar alShobuni, t.th

al-Suyuthi, Jalaluddin., al-Itqân Fî 'Ulûm al-Qur'ân, Damaskus: Dar Ibnu Katsir, 2000 M

Anis, Ibrahim., al-Mu jam al-Wasîth, Cairo, Majma` al-Lughah al'Arabiyyah

Asyur, Muhammad al-Thahir Ibnu., Tafsîr al-Tahrîr Wa al-Tanwîr, Tunisia: Dar Suhnun, 1997

Fathallah, Abdus Satar., al-Madkhal Ilâ al-Tafsîr al-Maudhû'i, Cet. Ke-2, Cairo: Dar al-Tauzî Wa al-Nasy alIslâmiyyah, $1991 \mathrm{M}$

Jamal, Abdul Basith., \& Jamal, Dalia Shadiq., Alquran dan Sains: Kehidupan Sosial Semut, www.republika.co.id

Khalifah, Ibrahim Abdurrahman Muhammad., al-Dakhîl Fî al-Tafsîr, Cairo: Diktat Perkuliahan Universitas Al Azhar, t.th

Mahran, Bayoumi., Banû Isrâ'îl, Iskandaria: Dar al-Ma`rifah alJami iyyah, 1999 M

-, Dirâsât Târîkhiyyah Min al-Qur'ân al-Karîm Fî Bilâd al-'Arab, Iskandaria: Dar al-Ma`rifah alJami`iyyah, 1995 M 
------, Dirâsât Târîkhiyyah Min al-Qur'ân al-Karîm Fi Misr, Iskandaria: Dar alMa`rifah al-Jami`iyyah, 1995 M

Ma'luf, Louis., al-Munjid Fi al-A'lam, Cet. Ke-15, Bairut: Dar al-Masyriq

Shamad, Muhammad Kamil Abdush., alI'jâz al-'Ilmi Fî al-Islâm (al-Qur'ân al-Karîm), Cet. Ke-4, Cairo: al-Dar al-Mishriyyah al-Libnaniyyah, 1996

Shihab, M. Quraish., Menabur Pesan Ilahi: Al-Quran Dan Dinamika Kehidupan Masyarakat, Jakarta, Lentera Hati, 2006

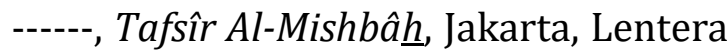
Hati, 2002

Thanthawi, Muhammad Sayyid., alTafsîr al-Wasîth Li al-Qur'ân alKarîm, Cairo: Dar al-Sa`adah, 2007

Tim Penyempurnaan Al-Qur'an dan Tafsirnya, Al-Qur'an dan Tafsirnya, Jakarta, Cet. Ke-4, Departemen Agama RI, 2009 M

Tim Penyusun Tafsir Alquran, alMuntakhab Fî Tafsîr al-Qur'ân alKarîm, Cet. Ke-9, Cairo: Kementerian Wakaq Republik Arab Mesir, 2000

Tim Penyusun Tafsir Ilmi, Hewan Dalam Perspektif Alquran dan Sains, Jakarta: Lajnah Pentashihan Mushaf Alquran, 2012

------, Penciptaan Manusia Dalam Perspektif Alquran dan Sains, Jakarta: Lajnah Pentashihan Mushaf Alquran, 2012

Umar, Ahmad., al-Tafsîr al-'Ilmi Li alQur'ân Fî al-Mîzân, Bairut: Dar Qutaibah, $1991 \mathrm{M}$

Washfi, Muhammad., al-Qur'ân Wa alThibb, Bairut: Dar Ibnu Hazm, 1995

Yusuf, Abdul Latif., Zubdah al-Mufradât, Bairut: Dar al-Ma`rifah, 1998 M 